\title{
PATTERN DESIGN OF TWISTED DRAPERIES WITH DECORATIVE AND CONSTRUCTIVE FUNCTION
}

\author{
Zlatina Kazlacheva \\ Faculty of Technics and Technologies, Trakia University, Bulgaria \\ Graf Ignatiev 38, 8600 Yambol, Bulgaria \\ e-mail: zlatinka.kazlacheva@trakia-uni.bg
}

\begin{abstract}
The paper presents a systemized approach of pattern design of twisted draperies with decorative and constructive function on the base of calculating compensation of shortening after twisting. The presented approach of constructing uses an investigation of obtaining of mathematical dependences on the base of the shortening of the piece in directions of width and height after twisting. The formulas, obtained with linear regressions, make pattern design of this type of drapery full systemized and lead to successful constructing of twisted pieces or parts of them in varied sizes. The pattern design of twisted draperies with decorative and constructive function is systemized with the use of dependence for calculation of the additional width for twisting. The systematization facilitates the processes of fashion and technical design leading to easy and successful constructing of drapery in different sizes of draped parts of clothing pieces, and giving possibilities for new creative ideas and variety of designs. It makes the presented systemized approach of pattern design very suitable for ready-to-wear industry.
\end{abstract}

Keywords: fashion design, pattern making, drapery, twisted draperies.

\section{INTRODUCTION}

An investigation about pattern making of twisted draperies has been made, in which extra width and height are added to the twisted piece [1]. The additional width and height are calculated by mathematical dependences based on the shortening of the piece in both directions after twisting. The formulas, obtained with linear regressions [2], make pattern design of this type of drapery full systemized and lead to successful constructing of twisted pieces or parts of parts of them in varied sizes. In [1] the pattern making system is presented with an example of design of twisted drapery, result of a piece twisting, with only decorative function. Different approaches of pattern making of this type drapery with decorative and constructive function are presented in [3], [4], [5], and [6], but without systematization which gives possibilities of varied sizes of draped pieces.

The paper presents a systemized approach of pattern design of twisted draperies with decorative and constructive function on the base of calculating compensation of shortening after twisting.

\section{DEPENDENCES FOR COMPENSATION OF SHORTENING AFTER TWISTING}

The approach of pattern design, presented in the paper, is based on dependences (1) and (2), which obtaining is shown in [1]:

$$
\begin{aligned}
& \text { Wadd }=-4,2+0,5 . \mathrm{Hp}, \\
& \text { Hadd }=-3,9+0,26 . \mathrm{Hp},
\end{aligned}
$$

IRTIIE Vol. 7, No. 1, 2019 ISSN 1314-8788 (print), ISSN 1314-8796 (online), doi: 10.15547/artte.2019.01.001 


\section{IRTITE

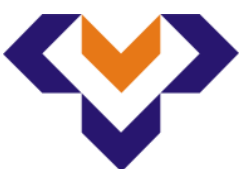

Ipplied Researl'hes in Technics, Technologies and Bduciation

Journal of the Faculty of Technics and Technologies, Trakia University https://sites.google.com/a/trakia-uni.bg/artte/

where Wadd, $\mathrm{cm}$ is additional width for compensating shortening of the piece width after twisting; Hadd, $\mathrm{cm}$ - additional height for compensating shortening of the piece height after twisting; $\mathrm{Hp}, \mathrm{cm}$ - height of the place of twisted piece.

Figures 1 and 2 show the place of twisting piece and the form of twisted piece with added width and height for compensation of shortening after twisting. The place of piece is approximated as a rectangle.

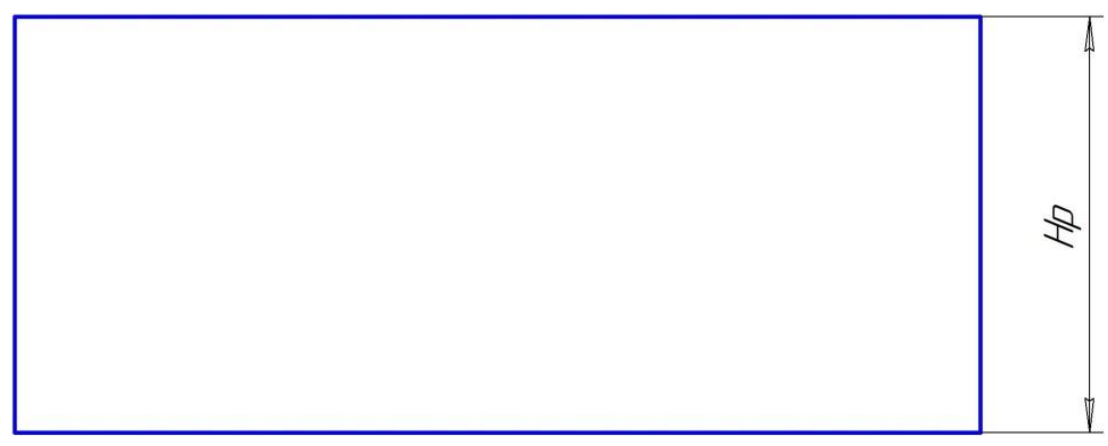

Figure 1. The place of twisted place

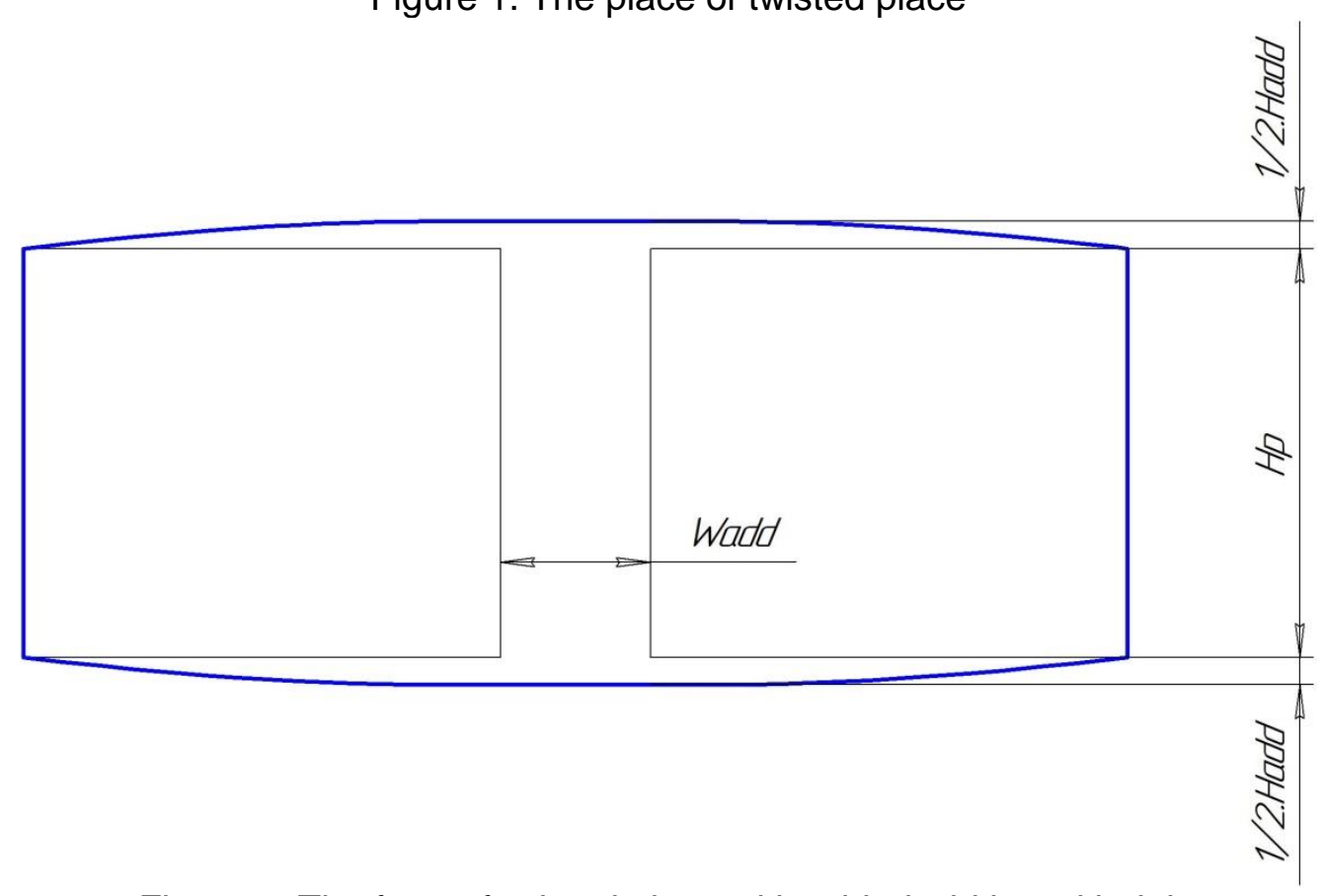

Figure 2. The form of twisted piece with added width and height for compensation of shortening after twisting

\section{SYSTEMIZED APPROACH OF PATTERN DESIGN OF TWISTED DRAPERIES WITH DECORATIVE AND CONSTRUCTIVE FUNCTION}

Figure 3 presents a lady's dress with twisted drapery with decorative and constructive function, asymmetrically located in the neckline. The place of drapery divides the neckline in Golden ratio proportion [7, 8]. Actually the model of the dress is transformation of a dress, presented in [8], in which the twist knot drapery is replaced with twisted one.

The way of pattern design is presented in Figures 4, 5, 6, 7, and 8.

IRTIIE Vol. 7, No. 1, 2019 ISSN 1314-8788 (print), ISSN 1314-8796 (online), doi: 10.15547/artte.2019.01.001 


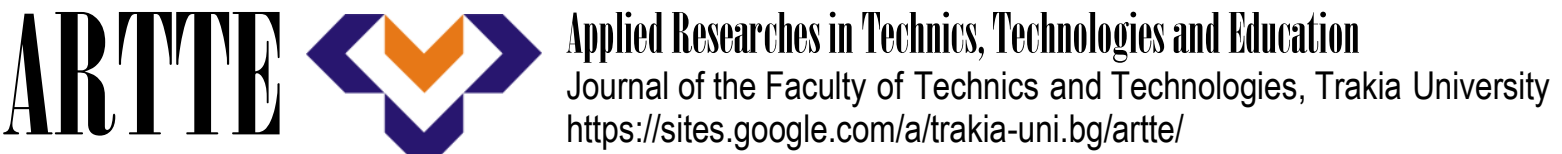

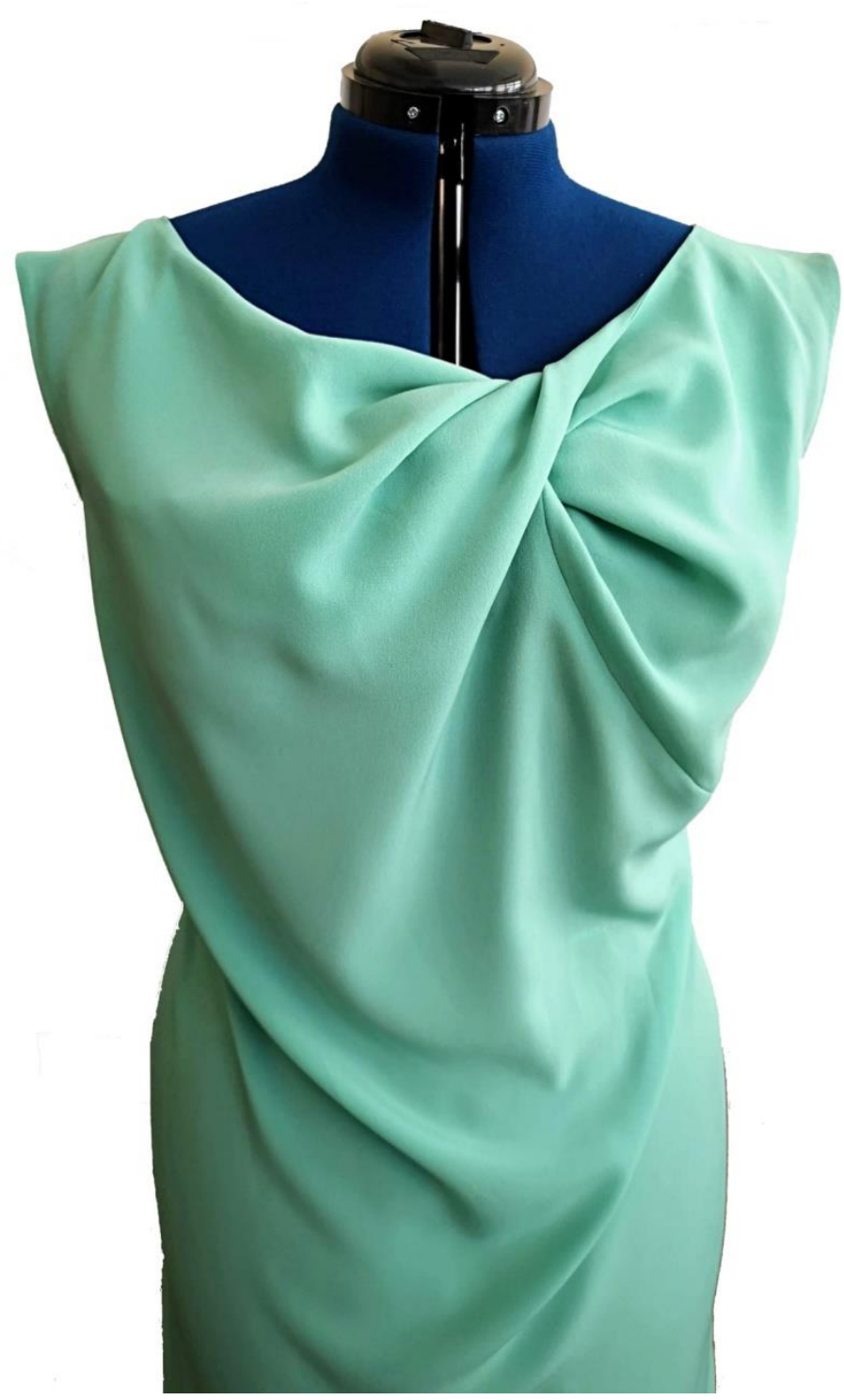

Figure 3. Design of a lady's dress with twisted drapery with decorative and constructive function

Figure 4 presents the front piece of a lady's dress. For facilitating of constructing the bust darts are rotated in the points of intersection between side seams and waist line. The neck opening is formed with an arc. The decorative and constructive seam, which divides the front in two pieces, is drawn with a curved line between the neckline and the point of intersection between the left side seam and waist. This seam is the line of fixing of the drapery. The seam divided the neck opening in Golden proportion. The place of the twisted drapery is in the connection between the neckline and the decorative and constructive seam. The place of the twisting is measured from the neckline on the seam and it is 4,0-5,0 cm, and the center point of this place is connected with apexes of the bust darts with straight lines. These straight lines define the main directions of the drape folds and they are the lines of dividing of the front pieces for the drapery. 


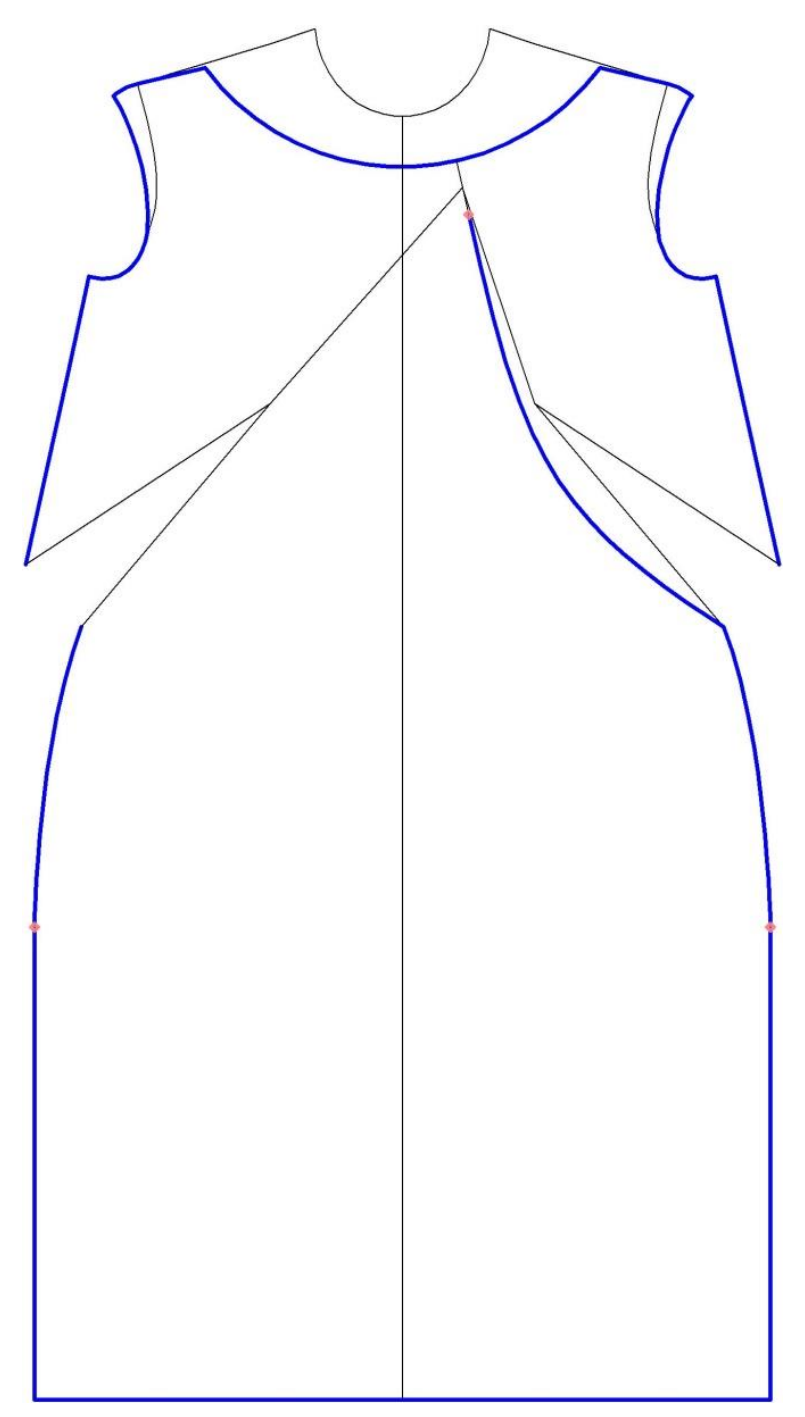

Figure 4. The place of twisting and lines of dividing of pieces for drapery

Figure 5 shows the openings for folds and volume of drapery in the pieces of the front. The bust darts are rotated and included in the divisions and by this reason the drapery is with both decorative and constructive function. Additional openings are made with help of rotation of divided pats around points of intersection between the side seams and waist. The height of drapery in the place of twisting $\mathrm{H}$ for both pieces is defined by place for twisting $(4,0-5,0$ $\mathrm{cm}$ on the fixing seam) plus the opening for folds and volume. In twisted drapery with decorative and constructive function the additional height for drapery is result of constructing and in connection with formula (2), the height of drapery can be defined with formula (3):

$$
\mathrm{H}=\mathrm{Hp}+\text { Hadd, }
$$

where $\mathrm{H}, \mathrm{cm}$ is the heights of drapery in the place of twisting; $\mathrm{Hp}, \mathrm{cm}$ - height of the place of twisted piece from formula (1); Hadd, $\mathrm{cm}$ - additional height for compensating shortening of the piece height after twisting from formula (1). 


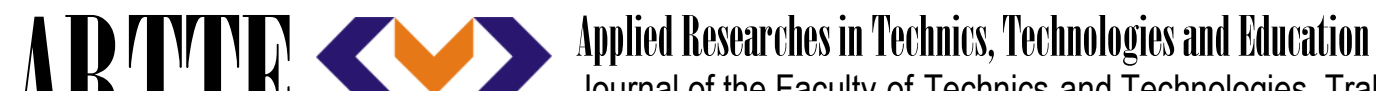 Journal of the Faculty of Technics and Technologies, Trakia University https://sites.google.com/a/trakia-uni.bg/artte/}

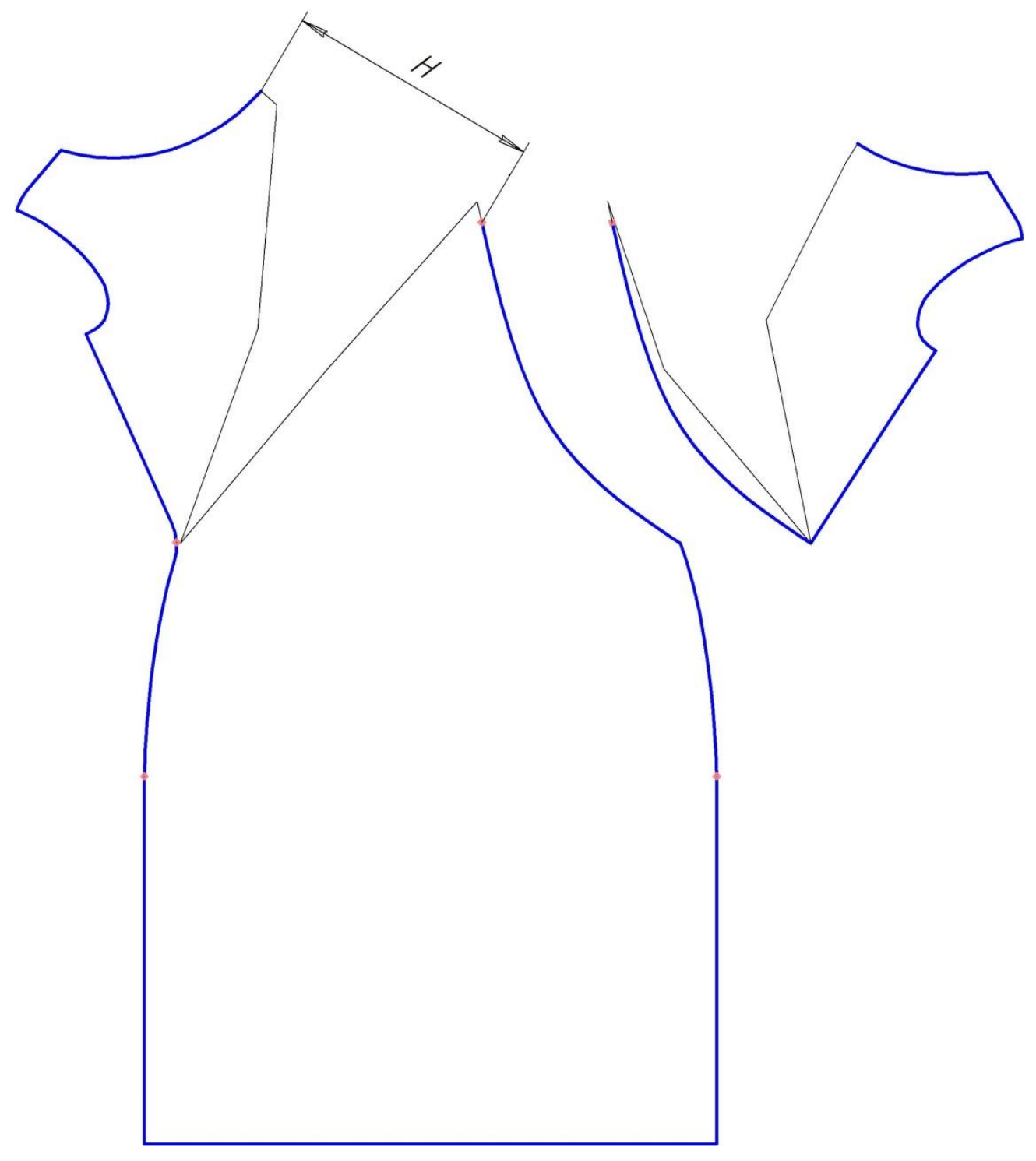

Figure 5. The height of twisted drapery $\mathrm{H}$

According to [1] $\mathrm{H}=15,0-30,0 \mathrm{~cm}$. Of course the bigger value of $\mathrm{H}$ leads to riches volume draperies with more intensive curves of folds.

Figure 6 presents the drawing of the width of the twisting and the forming of the place of twisting with rectangles in both pieces. The width of twisting or the width of the rectangles $\mathrm{W}$ is defined by the height of drapery or the height of the rectangles. In connection with formulas (1) and (2) the width of twisting is determined by formula (4):

$$
W=0,4 . H-2,65 \text {, }
$$

where $\mathrm{W}, \mathrm{cm}$ is the width of the twisting or the width of rectangles of twisting; $\mathrm{H}, \mathrm{cm}-$ the height of drapery or the height of the rectangles of twisting.

For presented design of lady's dress with twisted drape the height of drapery $\mathrm{H}=24,0 \mathrm{~cm}$ is chosen, result of bust dart transformation and additional opening. The width of twisting $\mathrm{W}=$ $6,95 \mathrm{~cm}$ is calculated with the use of dependence (4).

IRTIIE Vol. 7, No. 1, 2019 ISSN 1314-8788 (print), ISSN 1314-8796 (online), doi: 10.15547/artte.2019.01.001 


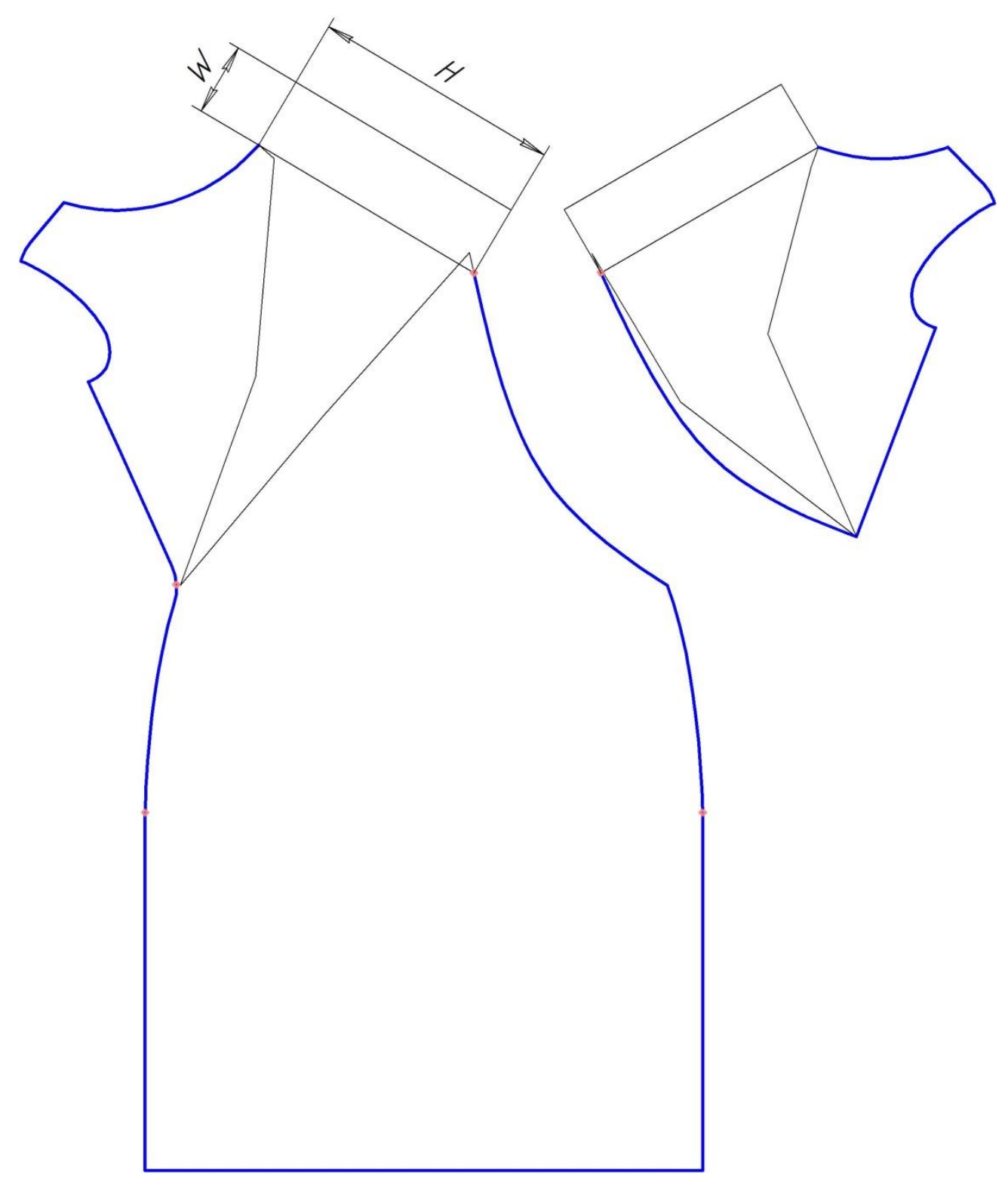

Figure 6. The width of twisted drapery $\mathrm{W}$ and forming of place of twisting with rectangles with width $\mathrm{W}$ and height $\mathrm{H}$

The investigation [1] is made only for woven fabrics. Therefore formulas (1), (2), (3) and (4) have to be used only in pattern designs of clothing made from woven fabrics. In the process of cutting the rectangle of twisting have to be situated in skew direction.

Figure 7 shows the design of patterns. In the bigger piece to the rectangle which forms the piece of twisting a mirror image of a part of smaller piece is added. The part of smaller piece is limited by the height of rectangle, the neckline and a segment of the shoulder. In the smaller piece to the rectangle which forms the piece of twisting a mirror image of a part of bigger piece is added. The part of bigger piece is limited by the height of rectangle, the neckline and a segment of the shoulder. 


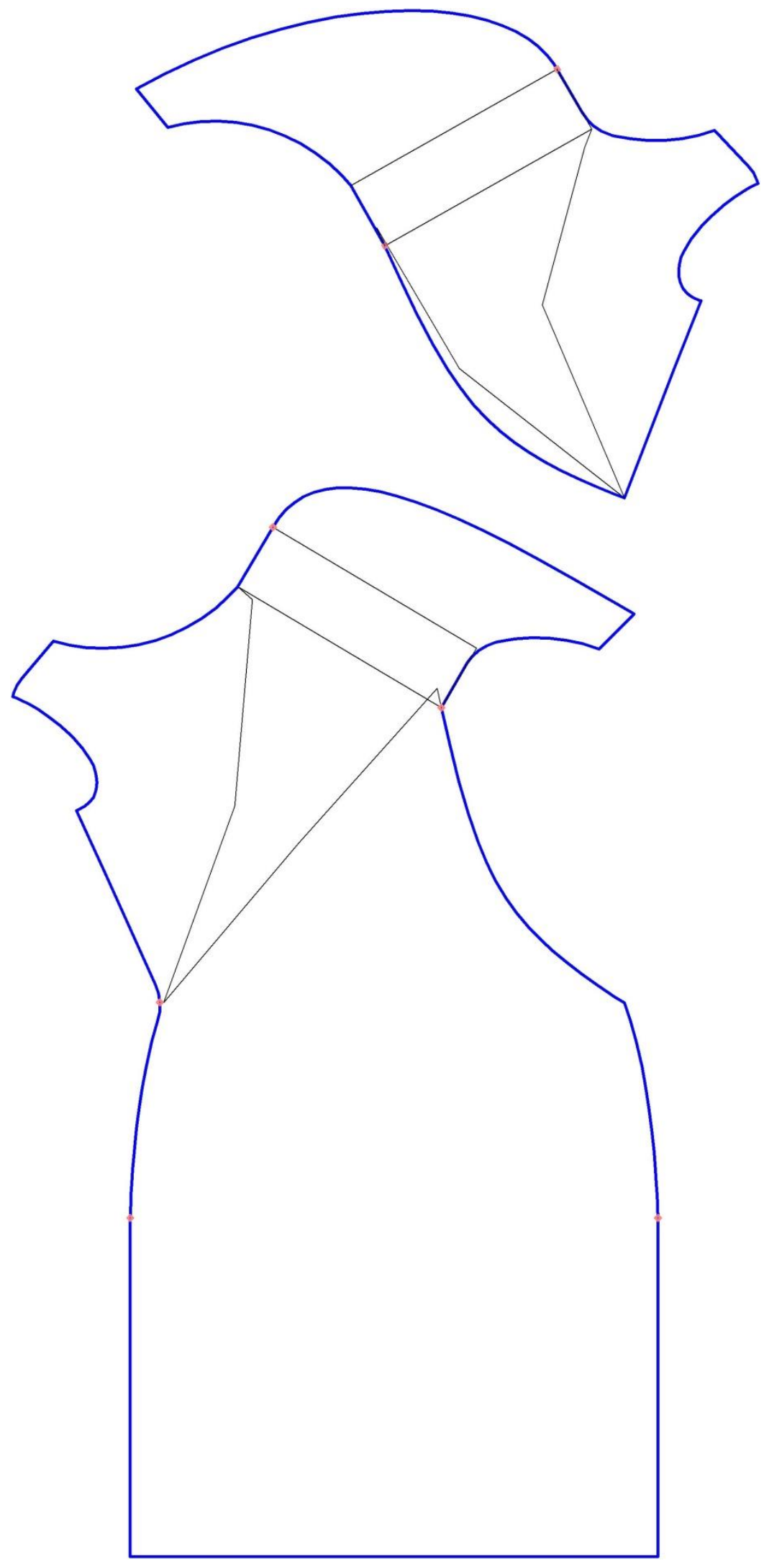

Figure 7. Pattern design with two pieces

IRTTIE Vol. 7, No. 1, 2019 ISSN 1314-8788 (print), ISSN 1314-8796 (online), doi: 10.15547/artte.2019.01.001 
Figure 8 presents the design of a pattern, only one piece, which can create a twisted drapery. It is possible if a double faced fabric is used.

Presented approach with the use of dependence (4) can be used for twisted drapery with only decorative function, which is formed by two pieces or one piece with seam or two seams of fixing of drapery.

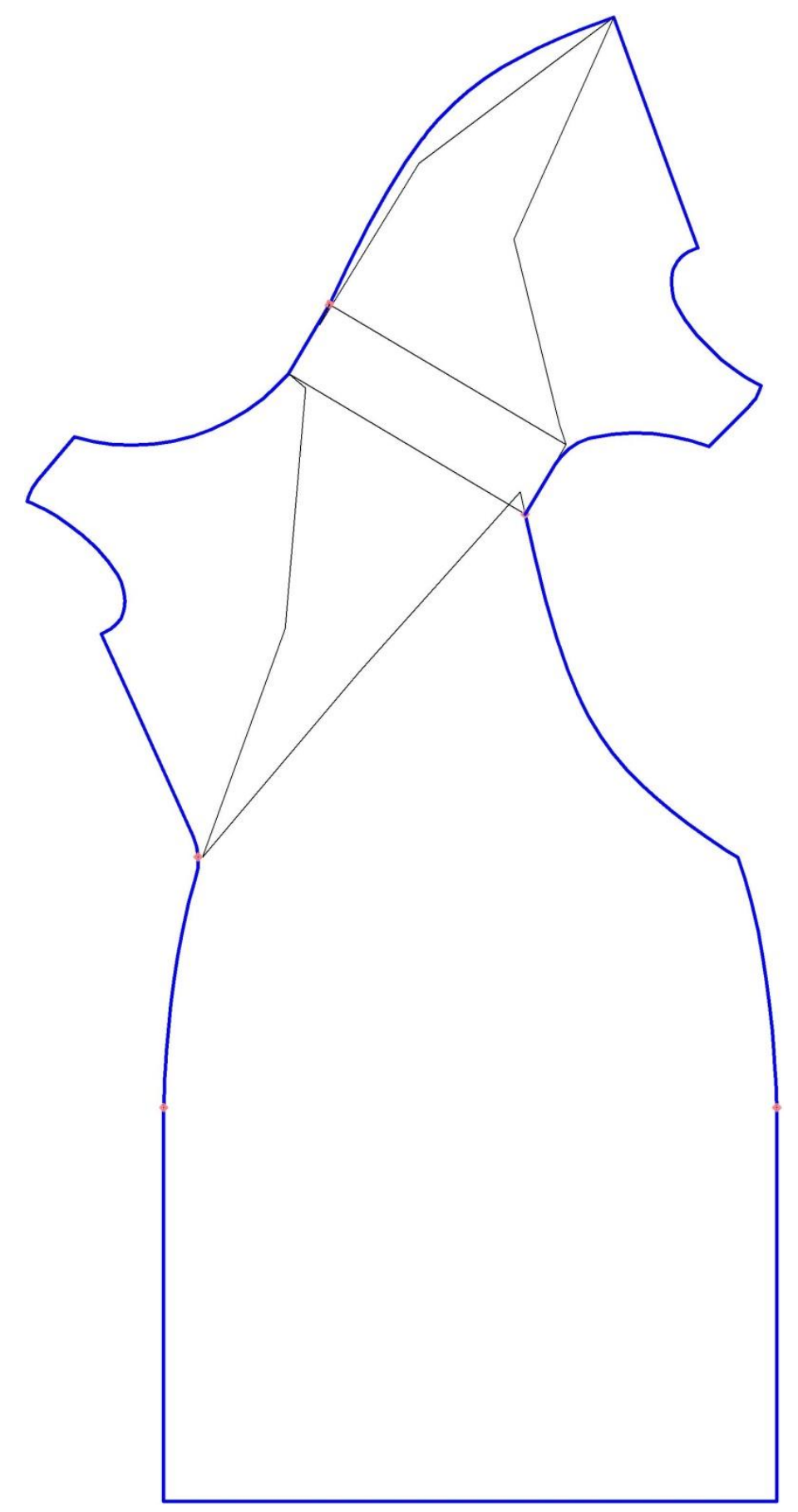

Figure 8. Pattern design with one piece

IRTIIE Vol. 7, No. 1, 2019 ISSN 1314-8788 (print), ISSN 1314-8796 (online), doi: 10.15547/artte.2019.01.001 


\section{ARTTE $Y$}

Ipplied Resseirlores in Technics, Technologies and Educration

Journal of the Faculty of Technics and Technologies, Trakia University https://sites.google.com/a/trakia-uni.bg/artte/

\section{CONCLUSIONS}

The pattern design of twisted draperies with decorative and constructive function is systemized with the use of dependence for calculation of the additional width for twisting. The systematization facilitates the processes of fashion and technical design leading to easy and successful constructing of drapery in different sizes of draped parts of clothing pieces, and giving possibilities for new creative ideas and variety of designs. It makes the presented systemized approach of pattern design very suitable for ready-to-wear industry.

\section{ACKNOWLEDGEMENTS}

The work is supported by the scientific project 2.FTT/ 2016 'Investigation of the Fashion Design and Pattern making of 3D Elements in Ladies' Clothing' funded by the Faculty of Technics and Technologies of Yambol, Trakia University of Stara Zagora, and the Fund of the National budget for scientific research in higher education in Bulgaria.

\section{REFERENCES}

[1] Kazlacheva Z., Dineva P. (2017). An Investigation of Pattern Making of Twisted Draperies. ARTTE Applied Researches in Technics, Technologies and Education, Vol. 5, No. 2, 2017, pp. 85-93. doi: 10.15547/artte.2017.02.002.

[2] Hill, T. \& Lewicki, P. (2007). Electronic Statistics Textbook. Available: http://statsoft.com/textbook/stathome.html [2007-2017].

[3] Nakamichi T. (2011). Pattern Magic 2. London, UK, Laurence King, 2011, ISBN 9781856697064.

[4] Joseph-Armstrong H. (2011). Patternmaking for Fashion Design. London, UK, Pearson Education, ISBN 970135018767.

[5] McAdam A. (2013). Pattern Puzzle - Twist and Turnback Top. [Online]. Available: https://studiofaro-wellsuited.blogspot.com/2013/11/pattern-puzzle-twist-and-turnbacktop.html [2018-2019].

[6] McAdam A. (2015). Pattern Insights - Jersey Twist Patterns. Online]. Available: http://www.studiofaro.com/well-suited/pattern-insights-jersey-twist-patterns [2018-2019].

[7] Kazlacheva Z. (2017). An Investigation of Application of the Golden Ratio and Fibonacci Sequence in Fashion Design and Pattern Making. $17^{\text {th }}$ World Textile Conference AUTEX 2017 - Textiles - Shaping the Future, 29-31 May 2017, Corfu, Greece, IOP Conf. Series: Materials Science and Engineering 254 (2017) 172013. doi:10.1088/1757899X/254/17/172013.

[8] Kazlacheva Z., Ilieva J. (2018). An investigation of Design of Twist Knot Drape Clothes. The Aegean International Textile and Advanced Engineering Conference AITAE 2018, 57 September 2018, Lesvos, Greece, IOP Conf. Ser.: Mater. Sci. Eng. 459 (2018) 012079. doi:10.1088/1757-899X/459/1/012079. 